\title{
Belgeo
}

Revue belge de géographie

2-3| 2004

Landscape research in Europe

\section{Landscape research in Slovenia}

La recherche paysagère en Slovénie

\section{Drago Perko and Mimi Urbanc}

\section{(2) OpenEdition}

Journals

\section{Electronic version}

URL: http://journals.openedition.org/belgeo/13618

DOI: 10.4000/belgeo.13618

ISSN: 2294-9135

\section{Publisher:}

National Committee of Geography of Belgium, Société Royale Belge de Géographie

\section{Printed version}

Date of publication: 30 September 2004

Number of pages: $347-360$

ISSN: 1377-2368

\section{Electronic reference}

Drago Perko and Mimi Urbanc, «Landscape research in Slovenia », Belgeo [Online], 2-3 | 2004, Online since 14 September 2013, connection on 07 July 2020. URL : http://journals.openedition.org/belgeo/ 13618 ; DOI : https://doi.org/10.4000/belgeo.13618

This text was automatically generated on 7 July 2020 .

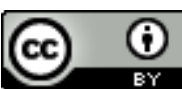

Belgeo est mis à disposition selon les termes de la licence Creative Commons Attribution 4.0 International. 


\title{
Landscape research in Slovenia
}

\author{
La recherche paysagère en Slovénie
}

\section{Drago Perko and Mimi Urbanc}

1 Relative to landscape diversity, only a few, even much larger countries can be compared to Slovenia because on this very tiny piece of Central Europe the Alps, the Pannonian plain, the Dinaric mountains, and the Mediterranean touch and intertwine, as do Germanic, Hungarian, Slavic, and Romanic cultural influences. For this reason Slovenia is renowned for its natural and cultural diversity, geographical variability, and transitional areas. Some consider it a natural geographical laboratory.

2 The Slovene language has two terms for "landscape": "pokrajina" and "krajina". A " pokrajina" is a spatial unit, part of the Earth's surface, a region, a complex of landscape elements, primarily a concept taken from science, while "krajina" is the external appearance, aspect, landscape painting, physiognomy, primarily a concept taken from art. Thus, for example, geographers use the term "pokrajina" while landscape architects use the term "krajina", even though they mean the same thing with the two expressions (Perko, 1998a, 14). A landscape painter is a "krajinar" in the Slovene language, his painting is a "krajina", and a landscape architect is a "krajinski arhitekt", while the parts of Slovene territory, for example, the Julian Alps or Karst (Kras in Slovene language), are called "pokrajina".

\section{Disciplines and fields of landscape research}

In Slovenia, geography plays the leading role in landscape research. A pioneering role was played by the geographer Anton Melik, a member of the Slovenian Academy of Sciences and Arts, who published the first regional monograph of Slovenia in four extensive volumes between 1954 and 1960 (Melik, 1954, 1957, 1959, 1960) as well as the first general monograph of Slovenia (Melik, 1963).

4 At Melik's initiative, the Slovenian Academy of Sciences and Arts founded the Geographical Institute in 1948, and this institute has carried his name since 1976. Almost half a century later, the Anton Melik Geographical Institute, which now works 
in the framework of the Scientific Research Centre of the Slovenian Academy of Sciences and Arts, prepared the second regional monograph of Slovenia entitled Slovenija - pokrajine in ljudje ("Slovenia - Landscapes and People"; Perko \& Orožen Adamiè, 1998) and the Geografski atlas Slovenije ("Geographical Atlas of Slovenia"; Fridl et al., 1998). Three years later, the Institute also prepared the first national atlas of the country, the National Atlas of Slovenia (Fridl et al., 2001), which was published in Slovene and English versions. All three books contain chapters on regionalization and the typification of landscapes in Slovenia with numerous maps. The Institute has also published numerous other publications about Slovene landscapes.

Another branch of the Scientific Research Centre of the Slovenian Academy of Sciences and Arts, the Karst Research Institute actively studies karst landscapes, primarily the landscape of Kras, the region of Slovenia where research into karst phenomena began on a world scale. Karst landscapes are very frequent in Slovenia since more than one half of its surface is covered by carbonate rock, the basis of karst landscapes.

6 Also active in the field of landscape studies are the Department of Geography of the Faculty of Arts of the University of Ljubljana - where academician Ivan Gams, author of the university textbook Essentials of Landscape Ecology (Gams, 1986) and several textbooks on the Slovene landscapes with maps of the regionalization of Slovenia (Gams, 1983, 1991, 2001, etc.), lectured for many years - and the Department of Geography of the Faculty of Education of the University of Maribor.

7 The main topics of studies by Slovene geographers have included the typification and regionalization of Slovene landscapes; landscapes of isolated farms; flood plain and karst landscapes; the influence of natural elements in shaping landscapes; changing land use and types of settlement; the changing of landscapes due to forest overgrowth, depopulation, urbanization, and economic activities (for example, the formation of a lake landscape above former mines); and the evaluation of landscapes relative to protecting the natural and cultural heritage, preserving the national identity, maintaining the ecologic balance, tourism, and other factors.

At the end of the 20th century, landscape architects were also more actively involved in landscape studies, as from certain viewpoints were pedologists, foresters, and agronomists as well. 
Table 1. Some basic characteristics of landscape types in Slovenia.

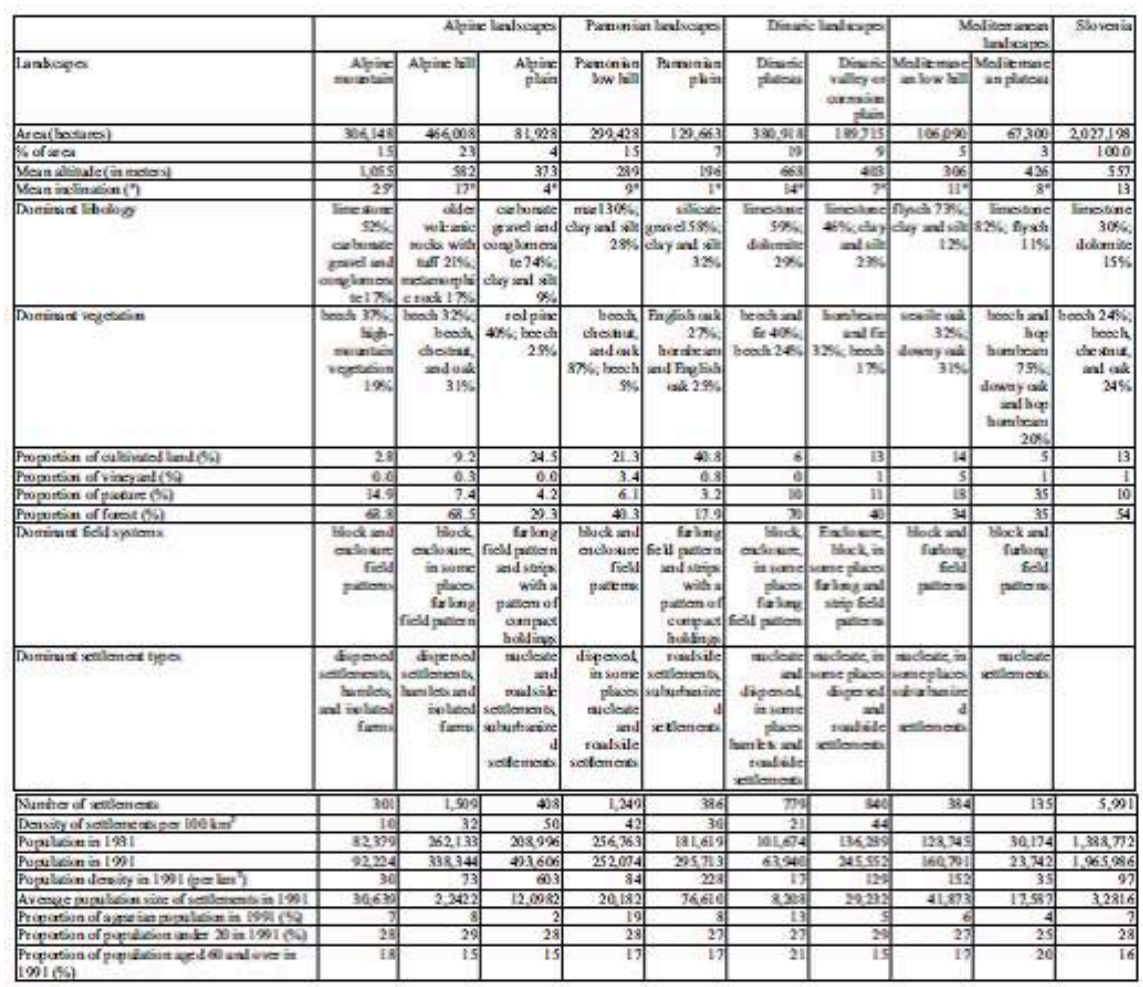

\section{Landscape types and regions}

9 The main characteristics of Slovenia's landscapes are determined by Slovenia's location at the juncture of the Alps, the Pannonian plain, the Dinaric mountains, and the Mediterranean. We can distinguish four basic landscape types and nine landscape subtypes. The basic types are Alpine, Pannonian, Dinaric, and Mediterranean landscapes, while the subtypes are Alpine mountain, Alpine hill, Alpine plain, Pannonian low hill, Pannonian plain, Dinaric plateau, Dinaric valley and corrosion plain, Mediterranean low hill, and Mediterranean plateau landscapes (Perko, 1998a; 1998, Urbanc, 2002).

10 The regionalization of Slovenia is also linked with the typification of landscapes. The majority of Slovene geographers divide Slovenia into four or five macroregions (the Alps or separately the Alps and Prealpine regions, the Pannonian plain, the Dinaric mountains, and the Mediterranean) that are further divided into forty to fifty mezzoregions.

\section{Stages of landscape development}

11 The long-term processes that shaped Slovenia's cultural landscapes during various historical periods overlapped and merged through time (see table 2). The period of medieval colonization was particularly significant since during that time the Slovene landscape acquired its most basic features (particularly the shape and arrangement of 
settlements, and the fields division), which with only partial changes have been preserved to the present day with only partial changes.

Table 2. Time line of the development of landscapes.

Image 2000000900003DAA000051419D35886B.wmf

\begin{tabular}{|c|c|c|c|}
\hline $\begin{array}{l}\text { Historical } \\
\text { period/time } \\
\text { frame }\end{array}$ & $\begin{array}{l}\text { Economic/political/ } \\
\text { social system }\end{array}$ & Main features & Traces \\
\hline $\begin{array}{l}\text { Prehistory/ } \\
145,000 \text { B.C. } \\
\text { to } 200 \text { B.C }\end{array}$ & & $\begin{array}{l}\text { Glaciation, shortage of } \\
\text { raw materials, sparse } \\
\text { settlement }\end{array}$ & Rare remains of settlements \\
\hline $\begin{array}{l}\text { Roman and } \\
\text { post } \\
\text { Roman } \\
\text { period } / 2^{\text {nd }} \\
\text { century B.C. } \\
\text { to } 6^{\text {th }} \\
\text { century A.D }\end{array}$ & & $\begin{array}{l}\text { Spread of Roman culture } \\
\text { and Latin language, } \\
\text { deforestation, start of } \\
\text { winegrowing }\end{array}$ & Road network, cities \\
\hline \multirow[t]{2}{*}{$\begin{array}{l}\text { Medieval } \\
\text { period } / 6^{\text {th }} \\
\text { century to } \\
15^{\text {th }} \text { century } \\
\text { A.D. }\end{array}$} & $\begin{array}{l}\text { Settlement of Slavs and } \\
\text { medieval colonization }\end{array}$ & \begin{tabular}{lrr} 
Slavic and & partly \\
Germanic & colonization by \\
free & farmers; \\
Romanization & in \\
hinterland of & coast; \\
Frankish rule & (8th \\
century) & \multicolumn{1}{c}{ brought } \\
Germanization, resumed \\
Christianization, r new \\
cultivation & methods, and \\
economic progress
\end{tabular} & $\begin{array}{l}\text { Number of settlements } \\
\text { reaches today's number: } \\
\text { nucleate, central, and } \\
\text { roadside villages; wooden } \\
\text { houses acquire more rooms; } \\
\text { field division into blocks, } \\
\text { primary furlongs, and strips; } \\
\text { isolated farms with } \\
\text { enclosures in hill and } \\
\text { mountain regions; mountain } \\
\text { pasturing; cities as economic, } \\
\text { cultural, and political centers; } \\
\text { today's language and dialect } \\
\text { mosaic }\end{array}$ \\
\hline & Feudalism & $\begin{array}{l}\text { Farmer serfs; } \\
\text { development } \\
\text { commerce and crafts; } \\
\text { beginnings of mining and } \\
\text { ironworks (13 }{ }^{\text {th }} \text { century); } \\
\text { wager } \\
\text { abandoning } \\
\text { agriculture; increasing } \\
\text { town } \\
\text { introduction of new crops: } \\
\text { corn, potato, and hops }\end{array}$ & $\begin{array}{l}\text { Reformation of irregular } \\
\text { forms of field division into } \\
\text { furlongs and strips with a } \\
\text { pattern of compact holdings; } \\
\text { country and city mansions; } \\
\text { monasteries; fragmentation of } \\
\text { property; stone houses of } \\
\text { wealthy farmers }\end{array}$ \\
\hline
\end{tabular}




\begin{tabular}{|c|c|c|c|}
\hline \multirow[t]{3}{*}{$\begin{array}{l}\text { Modern } \\
\text { history/15th } \\
\text { century to } \\
\text { today }\end{array}$} & Multinational states & $\begin{array}{l}\text { Habsburg Monarchy or } \\
\text { Austria-Hungary (1500- } \\
\text { 1918); industrialization } \\
\text { (1830); development of } \\
\text { transportation (1850); } \\
\text { collapse of agricultural } \\
\text { commerce and crafts; } \\
\text { partition of farm land and } \\
\text { decay of villages; collapse } \\
\text { of silk-making; decline of } \\
\text { winegrowing and } \\
\text { intensive introduction of } \\
\text { hop farming }\end{array}$ & $\begin{array}{l}\text { Manufacturing and industria } \\
\text { plants; settlements of } \\
\text { industry workers; Ljubljana } \\
\text { provincial capital with } \\
\text { cultural, educational, and } \\
\text { political role; non-farming } \\
\text { settlements: wagoners } \\
\text { cottagers, railroad workers } \\
\text { and ironworkers. Types of } \\
\text { houses that coincide with } \\
\text { former historic division into } \\
\text { provinces }\end{array}$ \\
\hline & & $\begin{array}{l}\text { Turkish Empire, raids } \\
\text { (from early 15th to late } \\
17 \text { th century), material } \\
\text { damage and casualties, } \\
\text { migrations, defense } \\
\text { system of marches }\end{array}$ & $\begin{array}{l}\text { Depopulation of individual } \\
\text { regions; refugee villages in } \\
\text { Slovene territory; fortified } \\
\text { encampments and churches }\end{array}$ \\
\hline & & $\begin{array}{l}\text { Kingdom of Yugoslavia } \\
\text { (1918-1945); emigration; } \\
\text { decline of agriculture }\end{array}$ & $\begin{array}{l}\text { Ljubljana: capital of truncated } \\
\text { Slovenia, economic core of } \\
\text { the new country }\end{array}$ \\
\hline Socialism & $\begin{array}{lr}\text { Partially } & \text { executed } \\
\text { agrarian } & \text { reform, } \\
\text { majority of } & \text { farm land } \\
\text { remains } & \text { private } \\
\text { property; polycentric } & \\
\text { development, } & \\
\text { urbanization, and } \\
\text { industrialization; } \\
\text { proportion of farmers } \\
\text { rapidly decreases; } \\
\text { development r of } \\
\text { transportation network }\end{array}$ & & $\begin{array}{l}\text { Small farm properties } \\
\text { survive; countryside remains } \\
\text { settled; class of part-time } \\
\text { farmers; previously large } \\
\text { properties are transformed } \\
\text { into combines; industria } \\
\text { buildings in the countryside } \\
\text { growing cities; non-farming } \\
\text { population dominates rura } \\
\text { settlements; uniform } \\
\text { semiurban house appears in } \\
\text { countryside }\end{array}$ \\
\hline
\end{tabular}

\section{Landscape evaluation and future development}

\section{Significance of the landscape}

12 The ecological significance of the landscape appears in the preservation of the natural balance. Constant maintenance of the cultural landscape with its many small elements that provide homes for plants and animals is at the same time the best protection against the natural disasters, primarily landslides and floods, that are most frequent in Slovenia. The preservation of the natural balance is of special importance in the ecologically less stable transition areas that dominate in Slovenia. The direct economic significance of the landscapes lies in the production of food. Slovenia has already passed 
the critical limit of food security because it has only 0.12 hectares of cultivated field per capita. Relative to the amount of agricultural land, Slovenia is within the European average with 0.44 hectares per inhabitant. However, the picture is particularly pessimistic because almost three quarters of Slovenia's agricultural land lies in less suitable regions and only one quarter in the plains and valleys (Gabrovec \& Kladnik, 1997, 11). The majority of Slovenia consists of rural landscapes with increasing tourism significance because its well-maintained cultural landscapes attract visitors, especially in the mountain and the hilly winegrowing regions. The diversity of landscapes is one of Slovenia's rare natural assets, since aside from forests it has few natural resources. The cultural-emotional significance depends largely on traditional farm landscapes with finely scattered parcels. Certain formations occupy an important place in the consciousness of slovenes and are important for their identity since they provide a feeling of belonging and home and show the way to historical roots.

\section{Threats to the landscape}

Rural landscapes encompass the greater part of Slovenia since infertile and built-up regions cover less than one tenth of its surface. Agriculture has given the basic appearance to the landscapes because at the beginning of the 20th century, farmers made up three quarters of the population (Kovaèiè, 1999, 55). Today, only six percent of the population is involved in farming, and the non-farming population owns a large proportion of the land. The abandoning of farm production, overgrowing, the restructuring of agriculture due to economic and social changes, and urbanization with its housing construction and building of infrastructure objects represent the greatest threats.

Forestation is linked to negative socioeconomic trends and the shift from the former maximum land use to the optimal land use of today, which leads to abandoning of land with poorer natural conditions, particularly in regions with higher altitudes and steep steeper hill slopes. This is the greatest threat to the Slovene landscape and has already reclaimed more than one tenth of agricultural land and soil. Forests now cover three fifths of Slovenia (Gabrovec \& Kladnik, 1997, 33).

Grassing over can be a consequence of redirecting agricultural production towards cattle into raising cattle or shortages of the lack of a rural labour force. It is occurring in all hill regions as well as on the plains due to the development of cattle raising. The amount of meadowland has increased constantly in the last hundred years.

Depopulation has affected almost half of Slovenia's territory since 1961. The population core has shifted in the last hundred years from the hilly Pannonian and Mediterranean worlds to the valleys and plains. Settlements have concentrated in a belt stretching to 400 meters above sea level in which some four fifths of Slovenia's entire population lived by 1991 (Perko, 1998b 1998d, 283).

Intensification and specialization are characteristic of regions where large-scale land improvement was carried out or where vineyards and orchards were expanded on a large scale, primarily in the naturally most advantageous regions and regions in the immediate vicinity of cities and towns (Gabrovec \& Kladnik, 1997, 57).

18 The deterioration of the architectural heritage has spread throughout the entire country. On one hand is the abandoning of former homes due to migration, and on the other is 
the introduction of new architectural elements that no longer have any local or regional character but are uniform across Slovenia.

\section{Possible future development}

19 In recent decades, a laissez-faire approach began to appear that will continue, particularly after inclusion in the European Union, if Slovenia is unable to acquire special status in agriculture due to its natural limitations and historic development. Free market policies will further accelerate the differentiation of the countryside, which is already acquiring clear outlines. In naturally more advantageous regions, intensive farming with large-scale cultivation is developing, which requires large consolidated surface areas without disturbing elements (e.g., hedges, free-standing trees, the traditional kozolec or hayrack). Small land division with its cultural riches is disappearing due to monocultural farming. The architectural heritage is disappearing because houses in the countryside and in the city are acquiring a uniform appearance. The production buildings on these farms are moving onto open spaces. A new and uniform type of landscapes without regional or local features is developing. At the same time, the valleys and basins are centres of civilization where numerous activities intertwine and various users of the space compete with each other. First class agricultural land is disappearing due to expressways and the territorial growth of cities. Rural settlements are acquiring the status of suburbs, and the countryside as a whole is acquiring a different role since it is becoming a place of residence and recreation for the non-farming population. The boundaries between cities and the countryside are already quite indistinct in Slovenia. At the same time, the cultural landscape in the greater part of Slovenia is disintegrating, primarily in the low-hill and hill regions. A largely aging population remains on the farms, who are emotionally bound to the land and for the moment still maintain the appearance and function of the landscape with their work. However, further abandonment of agricultural areas is to be expected in future since there are no young people except in areas closer to cities, and these no longer cultivate the land because their education allows them to work in better-paid non-farming jobs. The complete liberalization of the agricultural market would cause a considerable decrease in the number of farms and the gradual emptying of low-hill and remote regions and thus the loss of the identity of the countryside. Relative to the natural and historical heritage, the only acceptable model is the sustainability approach that envisages a development toward the restoration of the landscape with respect to biotic diversity, ecological balance, and the cultural heritage. This concept advocates the preservation of a sufficient number of farms and economic and technological development that would simultaneously respect market laws and the fundamental cultural elements of the landscape. In this way, Slovenia's cultural landscapes will continue to live as a reflection of former and current human activity.

Figure 1. The kozolec or hayrack is an achievement of folk architecture. Characteristically Slovene, they are used for drying crops and are found most frequently in alpine regions. (Photography: Oskar Dolenc). 


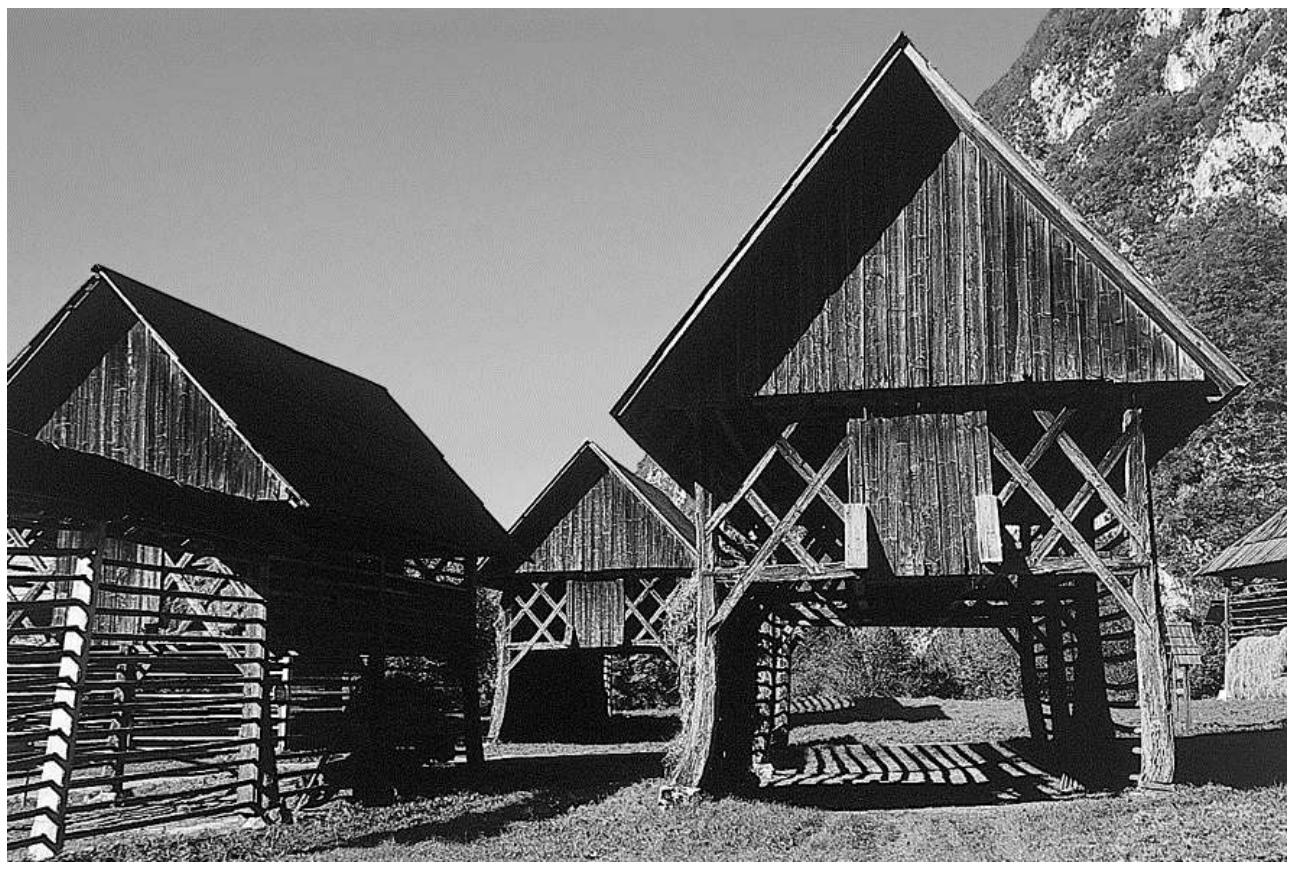

Figure 2. The klopotec or wind rattle is a wooden device to drive birds from the vineyards of the Pannonian low hills in Eastern Slovenia before and during the vintage time. (Photography: Milan Klemenèiè).

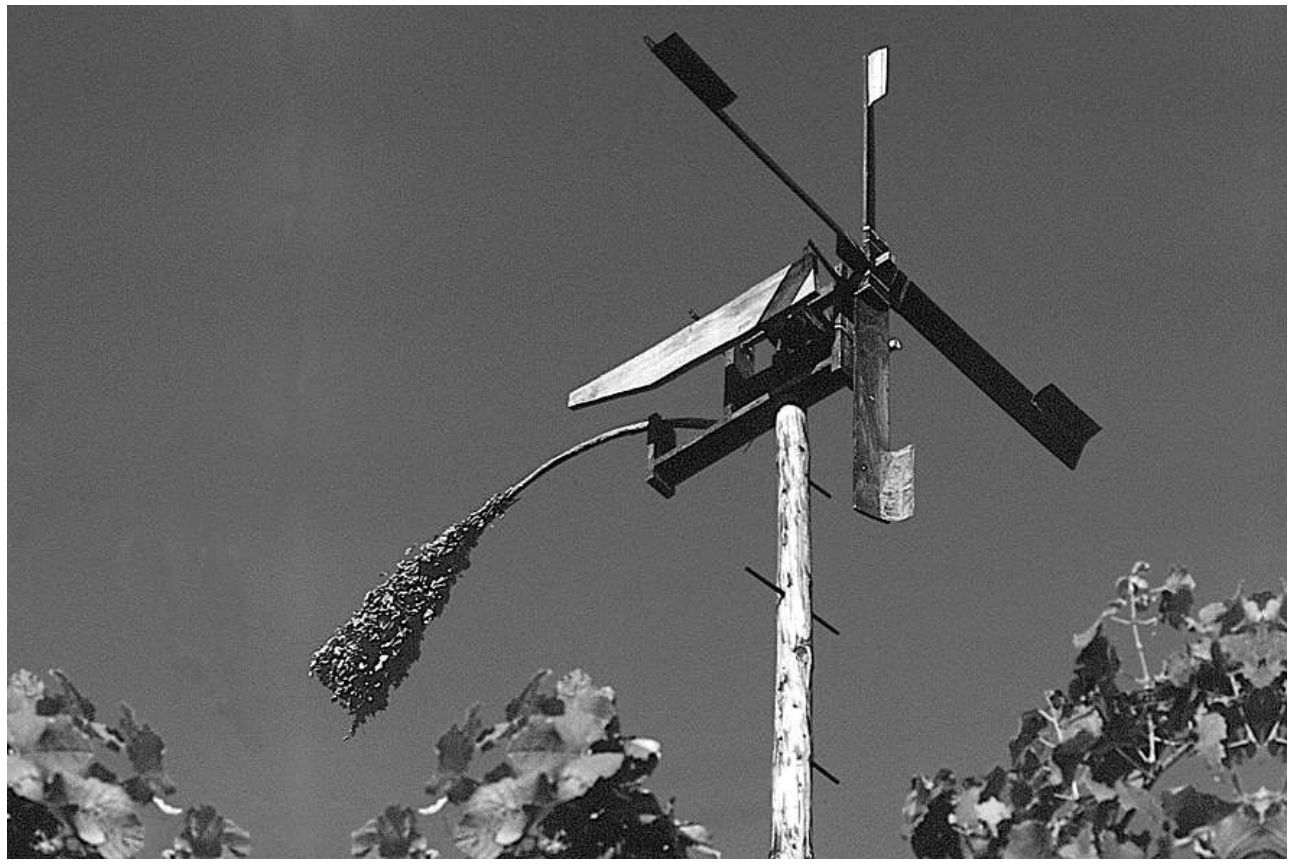

Figure 3. Ostrnice are thinner tree trunks with branches pushed into the ground on which hay is still dried in some Dinaric regions in Southern Slovenia. (Photography: Matej Gabrovec). 


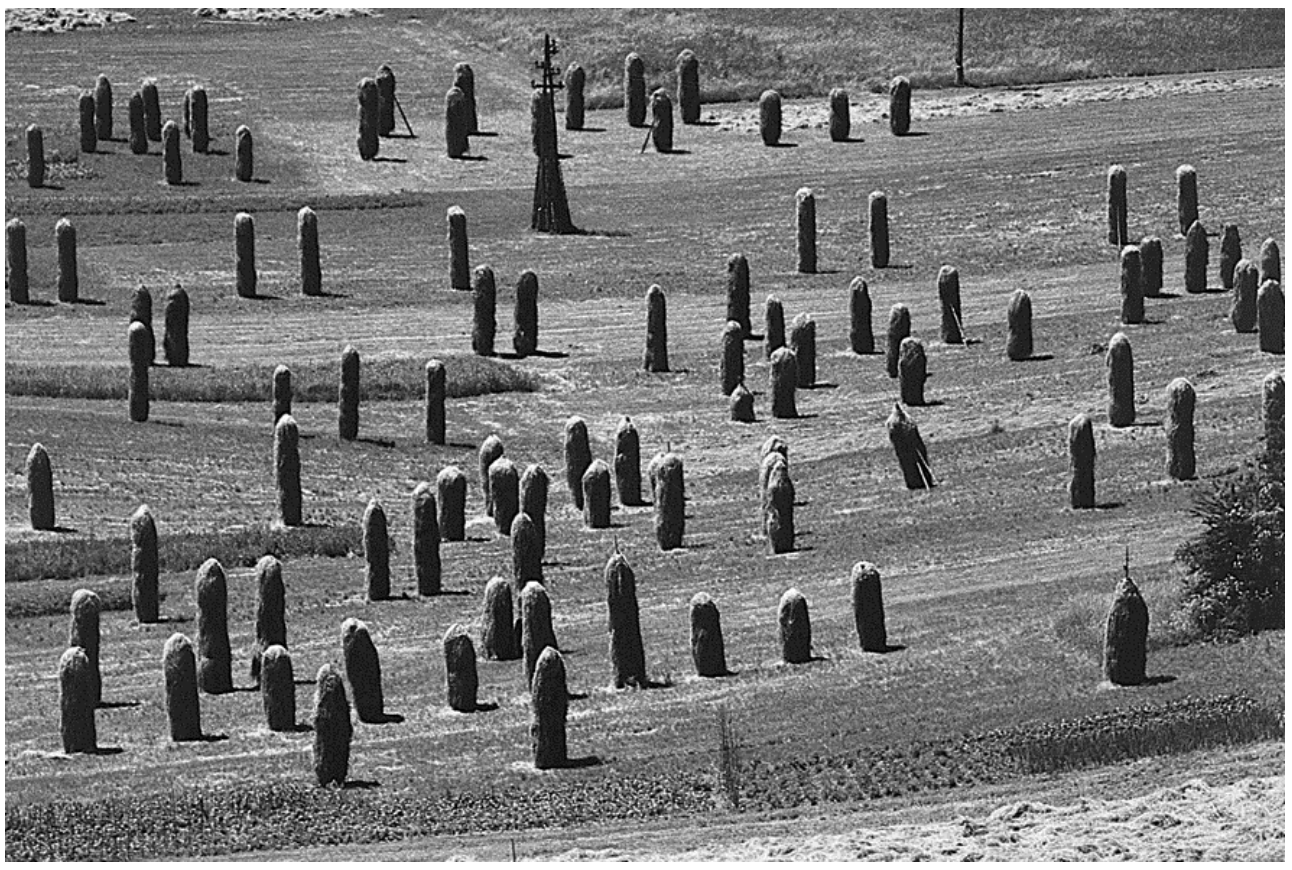

Figure 4. Piran, an old Mediterranean town, situated at the cape of the Piran peninsula, is actually an open air museum with the medieval architecture and rich culture heritage. (Photography: Marjan Garbajs).

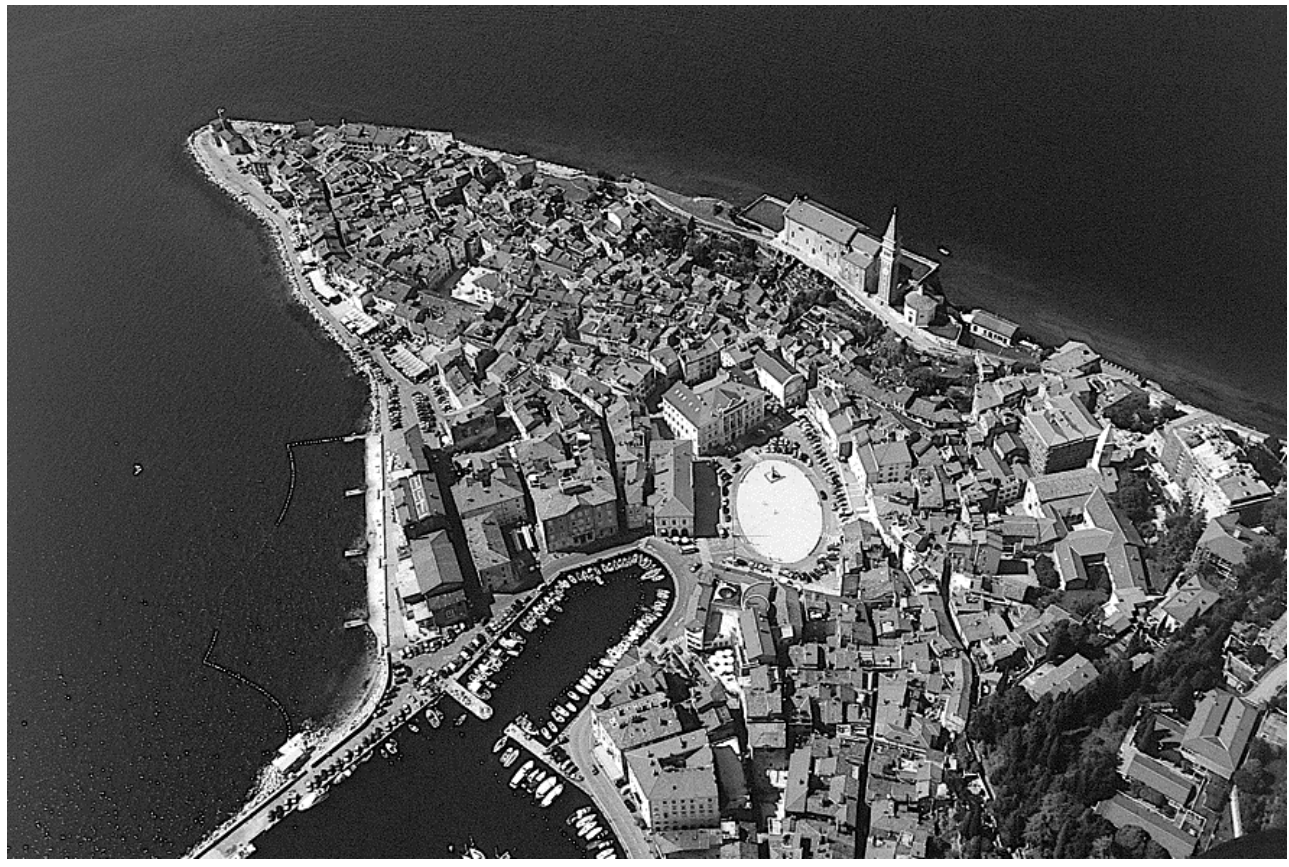

Figure 5. Landscape types in Slovenia. 


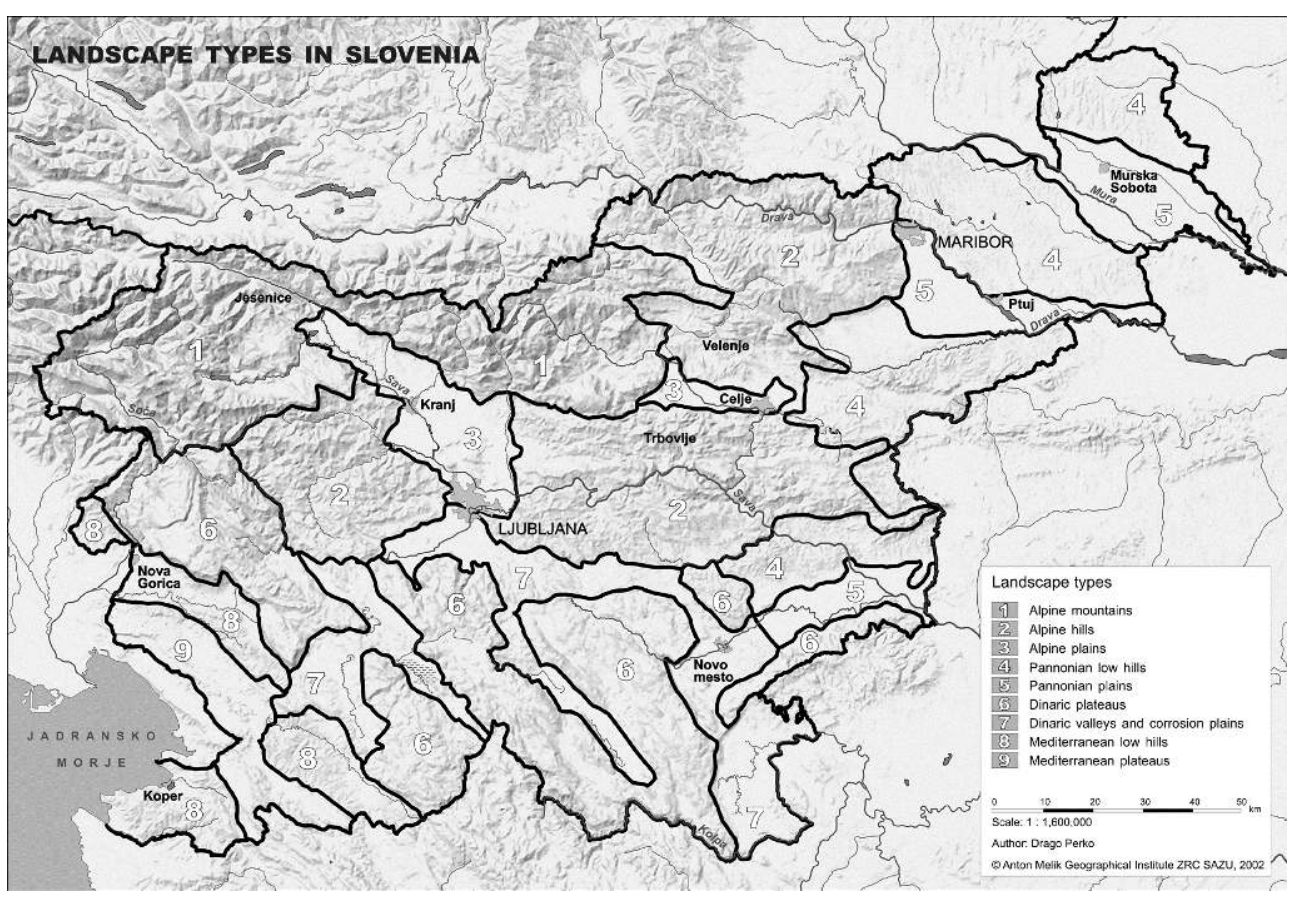

\section{BIBLIOGRAPHY}

ANKO B. (1983), Celek kot krajinskoekološka enota gozdne krajine, Ljubljana, Oddelek za gozdarstvo Biotehniške fakultete Univerze v Ljubljani.

BAT M. (1990), "Vpliv fiziènogeografskih dejavnikov na rabo tal (na primeru treh krajev v predalpskem hribovju Slovenije)", Geografski zbornik/Acta geographica, 30, Ljubljana Znanstvenoraziskovalni center SAZU, Geografski inštitut, pp. 69-127.

BLAZNIK P. et al. (1970), Gospodarska in družbena zgodovina Slovencev. Zgodovina agrarnih panog, Agrarno gospodarstvo (Economic and social history of Slovenes. History of agrarian branches, Agrarian economy), Ljubljana, Državna založba Slovenije.

BOŠTJANÈIÈ J., ZAFRAN J. (1998), “Analiza strukturnih sprememb kulturne krajine na primeru katastrske obèine Slavina" ("Analysis of structural changes of cultural landscape at the example of the Slavina cadastral community"), Gozdarski vestnik, 56-4, pp. 211-222, Ljubljana, Zveza gozdarskih društev Slovenije.

BOŽIÈ D. et al. (1999), Zakladi tisoèletij: zgodovina Slovenije od neandertalcev do Slovanov (Treasures of millennium: Slovenia's history from the Neanderthal man to the Slavs), Ljubljana, Modrijan.

CUNDER T. (1998), “Zarašèanje kmetijskih zemljišè v slovenskem alpskem svetu”, Sonaravni razvoj v slovenskih Alpah in sosedstvu, Dela, 13, Ljubljana, Filozofska fakulteta, Oddelek za geografijo, pp. 165-176.

DROZG V. (1995), Morfologija vaških naselij v Sloveniji (Morphology of rural settlements in Slovenia), Ljubljana, Inštitut za geografijo. 
FERENC M. (1993), Gottschee: the lost cultural heritage of the Gottscheer Germans (Koèevska: izgubljena kulturna dedišèina koèevskih Nemcev), Ljubljana, Ministrstvo za kulturo, Zavod Republike Slovenije za varstvo naravne in kulturne dedišèine.

FISTER P. et al. (1993), Architectural landscapes and regions of Slovenia (Arhitekturne krajine in regije Slovenije), Ljubljana, Ministrstvo za okolje in prostor Republike Slovenije, Zavod Republike Slovenije za prostorsko planiranje.

FRIDL J., KLADNIK D., OROŽEN ADAMIÈ M., PERKO D., ZUPANÈIÈ J. (eds.) (1998), Geographical atlas of Slovenia (Geografski atlas Slovenije), Ljubljana, DZS.

FRIDL J., KLADNIK D., OROŽEN ADAMIÈ M., PERKO D., ZUPANÈIÈ J. (eds.) (2001), National atlas of Slovenia, Ljubljana, Rokus.

GABRIJELÈIÈ P. (1985), Varstvo in urejanje kulturne krajine, Ljubljana, Fakulteta za arhitekturo, gradbeništvo in geodezijo.

GABROVEC M. (1990), "Pomen reliefa za geografsko podobo Polhograjskega hribovja” (Relief significance for geographical aspect of the Polhov Gradec mountains), Geografski zbornik/Acta geographica, 30, pp. 5-68, Ljubljana, Znanstvenoraziskovalni center SAZU, Geografski inštitut.

GABROVEC M., KLADNIK D. (1997), "Some new aspects of land use in Slovenia”, Geografski zbornik/ Acta geographica, 37, Ljubljana, Znanstvenoraziskovalni center SAZU, Geografski inštitut, pp. 7-64.

GAMS I. (1959), Pohorsko Podravje: razvoj kulturne pokrajine (Développement du paysage culturel), Ljubljana, Slovenska akademija znanosti in Umetnosti.

GAMS I. (1986), Osnove pokrajinske ekologije (Essentials of landscape ecology), Ljubljana, Filozofska fakulteta.

GAMS I. (2001), Geographical characteristics of Slovenia (Geografske znaèilnosti Slovenije), Ljubljana, Mladinska knjiga.

HOLZ E. (1994), Razvoj cestnega omrežja na Slovenskem ob koncu 18. in v 19. stoletju, Ljubljana, Znanstvenorazi skovalni center SAZU.

ILEŠIÈ S. (1950), Sistemi poljske razdelitve na Slovenskem (La physionomie parcellaire des champs en Slovénie), Ljubljana, Slovenska akademija znanosti in umetnosti.

ILEŠIÈ S. (1979), Pogledi na geografijo, Ljubljana, Partizanska knjiga.

KLEMENÈIÈ M. (1974), Socialni prelog kot indikator transformacije pokrajine v Sloveniji, Ljubljana, RSS.

KLEMENÈIÈ M. (1987), "Sistemska teorija: pot k novi regionalni geografiji (Sistem theory: a way to modern regional geography)”, Dela, 4, pp. 32-40, Ljubljana, Znanstveni inštitut Filozofske fakultete.

KLEMENÈIÈ V. (1989), "Med antropogeografijo in socialno geografijo na ljubljanski univerzi (Der Weg von Anthropo- zur Sozialgeographie an der Universität von Ljubljana)”, Dela, 6, pp. 22-29, Ljubljana, Znanstveni inštitut Filozofske fakultete.

KLEMENÈIÈ V. (1991), “Tendence spreminjanja slovenskega podeželja”, Geografski vestnik, 63, pp. 25-40, Ljubljana, Zveza geografskih društev Slovenije.

KOSI M. (1998), Potujoèi srednji vek: cesta, popotnik in promet na Slovenskem med antiko in 16. stoletjem, Ljubljana, ZRC SAZU.

KOVAÈIÈ M. (1999), "Razvojne tendence v kmetijstvu Slovenije in vpliv na kulturno krajino”, Kulturna krajina $v$ dinamiki varstva in razvoja, pp. 53-59, Ljubljana, Društvo krajinskih arhitektov Slovenije. 
KUÈAN A. (1998), Krajina kot nacionalni simbol (Landscape as a national symbol), Ljubljana, Znanstveno in publicisticno središèe.

LOVRENÈAK F. (1996), “O uporabi pojma pokrajina”, Geografski vestnik, 68, Ljubljana, Zveza geografskih društev Slovenije, pp. 265-266.

MARUŠIÈ I. et al. (1998a), Karst landscapes of Inner Slovenia (Kraške krajine notranje Slovenije), Ljubljana, Ministrstvo za okolje in prostor RS, Urad RS za prostorsko planiranje.

MARUŠIÈ I. et al. (1998b), Landscapes of Alpine region (Krajine alpske regije), Ljubljana, Ministrstvo za okolje in okolje in prostor RS, Urad RS za prostorsko planiranje.

MARUŠIÈ I. et al. (1998c), Landscapes of Mediterranean region (Krajine primorske regije), Ljubljana, Ministrstvo za okolje in prostor RS, Urad RS za prostorsko planiranje.

MARUŠIÈ I. et al. (1998d), Landscapes of Prealpine region (Krajine predalpske regije), Ljubljana, Ministrstvo za okolje in okolje in prostor RS, Urad RS za prostorsko planiranje.

MARUŠIÈ I. et al. (1998e), Landscapes of Sub Pannonian region (Krajine subpanonske regije), Ljubljana, Ministrstvo za okolje in prostor RS, Urad RS za prostorsko planiranje.

MEJAÈ Ž. (ed.) (1993), Tipološka klasifikacija krajine (Typological landscape classification, Ljubljana, Ministrstvo za okolje in prostor, Urad RS za prostorsko planiranje.

MELIK A. (1954), Slovenski alpski svet, Ljubljana, Slovenska matica.

MELIK A. (1957), Štajerska s Prekmurjem in Mežiško dolino, Ljubljana, Slovenska matica.

MELIK A. (1959), Posavska Slovenija, Ljubljana, Slovenska matica.

MELIK A. (1960), Slovensko primorje, Ljubljana, Slovenska matica.

MELIK A. (1963), Slovenija: geografski opis, Ljubljana, Slovenska matica.

MEZE D. (1965), “Samotne kmetije v Luèki pokrajini” ("Les fermes isolées dans la région de Luèe)”, Geografski zbornik/Acta geographica, 9, pp. 181-243, Ljubljana, Znanstvenoraziskovalni center SAZU, Geografski inštitut.

JAVORNIK M., VOGLAR D., DERMASTIA A. (eds.) (1987-2001), Enciklopedija Slovenije 1-15, Ljubljana, Mladinska knjiga.

OROŽEN ADAMIÈ M., PERKO D., KLADNIK D. (eds.) (1995), Lexicon of settlements in Slovenia (Krajevni leksikon Slovenije), Ljubljana, DZS.

MLAKAR A. (ed.) (1999), Kulturna krajina v dinamiki razvoja in varstva, Ljubljana, Društvo krajinskih arhitektov Slovenije.

OGORELEC B. (1987), “Za pomensko razmejitev med pokrajino in krajino in proti njej”, Geografski vestnik, 59, pp. 133-139, Ljubljana, Zveza geografskih društev Slovenije.

OGRIN D. (1997), Slovenian landscapes (Slovenske krajine), Ljubljana, DZS.

PERKO D. (1995), “Slovenija in njene pokrajine”, Mali atlas Slovenije, 3, Ljubljana, DZS.

PERKO D. (1997), “Slovenija na stiku velikih evropskih pokrajinskih enot”, Traditiones, 26, Ljubljana, Slovenska akademija znanosti in umetnosti, pp. 31-47.

PERKO D. (1998a), “Geography, region and regionalization (Geografija, regija in regionalizacija)”, Slovenija - pokrajine in ljudje, 12-15, Ljubljana, Založba Mladinska knjiga.

PERKO D. (1998b), "Prebivalstvo”, Geografija Slovenije, pp. 270-309, Ljubljana. Slovenska matica. 
PERKO D. (1998c), “The regionalization of Slovenia”, Geografski zbornik/Acta geographica, 38, 11-57, Ljubljana, Znanstvenoraziskovalni center SAZU, Geografski inštitut.

PERKO D. (1998), “Tipizacija in regionalizacija Slovenije”, Geografski obzornik, 45-1, 12-17, Ljubljana, Zveza geografskih društev Slovenije.

PERKO D. (1998), “Geografija, regija in regionalizacija”, Slovenija - pokrajine in ljudje, 12-15, Ljubljana, Založba Mladinska knjiga.

PERKO D. (2001), Analiza površja Slovenije s stometrskim digitalnim modelom reliefa (Analysis of the surface of Slovenia using the 100-meter digital elevation model, Ljubljana, ZRC SAZU.

PERKO D., OROŽEN ADAMIÈ M. (eds.) (1998), Slovenia - landscapes and people (Slovenija - pokrajine in ljudje), Ljubljana, Mladinska knjiga.

STRITAR A. (1990), Krajina, krajinski sistemi/raba tal in varstvo tal v Sloveniji, Ljubljana, Partizanska knjiga.

URBANC M. (2002a), Kulturne pokrajine v Sloveniji (Cultural landcapes in Slovenia, Ljubljana, ZRC

SAZU.

URBANC M. (2002b), Poskus tipologije kulturnih pokrajin v Sloveniji, Ljubljana, Oddelek za geografijo Filozofske fakultete Univerze v Ljubljani.

VOJVODA M. (1965), Razvoj kulturne pokrajine v Bohinju, Ljubljana, Oddelek za geografijo Filozofske fakultete Univerze v Ljubljani.

ZGONIK M., (1977), Dravska dolina: novejši razvoj kulturne pokrajine, Maribor, Obzorja.

\section{ABSTRACTS}

Slovenia lies at the junction of the Alps, the Pannonian plain, the Dinaric mountains, and the Mediterranean and underwent Germanic, Romanic, Hungarian, and Slavic cultural influences. For this reason, its landscapes are very diverse. We distinguish four basic landscape types (Alpine, Pannonian, Dinaric, and Mediterranean) and nine landscape subtypes (Alpine mountain, Alpine hill, Alpine plain, Pannonian low hill, Pannonian plain, Dinaric plateau, Dinaric valley, Mediterranean low hill, and Mediterranean plateau). The basic appearance of Slovene landscapes was formed in the period of medieval colonization and later changed only slowly. It is distinguished by its diversity, its incorporation in the natural environment, and high ecological and cultural-emotional value. Economic and social developments in recent decades have triggered rapid changes in the appearance and function of the landscape.

Située entre les Alpes, les plaines panoniennes, les chaînes dinariques et la Méditerranée, la Slovénie est dotée d'une grande diversité de paysages. Elle a subi l'influence des cultures germanique, romane, hongroise et slave. La Slovénie est divisée en quatre principaux types de paysages (alpin, panonien, dinarique et méditerranéen) et en neuf sous-types (les montagnes alpines, les collines alpines, la plaine alpine, les basses collines panoniennes, la plaine panonienne, le plateau dinarique, la vallée dinarique, les basses collines méditerranéennes et le plateau méditerranéen). Le paysage slovène s'est formé pendant la période de conquêtes du Moyen-Age et s'est depuis lentement transformé. Ce n'est qu'à partir des années soixante-dix du siècle dernier, avec le développement économique et social, que le paysage et sa structure ont subi des modifications plus rapides et importantes. 
INDEX

Mots-clés: paysage, région, typologie, Slovénie

Keywords: landscape, region, typology, Slovenia

\section{AUTHORS}

\section{DRAGO PERKO}

Anton Melik Geographical Institute, Scientific Research Centre of the Slovenian Academy of Sciences and Arts, drago@zrc-sazu.si

\section{MIMI URBANC}

Anton Melik Geographical Institute, Scientific Research Centre of the Slovenian Academy of Sciences and Arts, mimi@zrc-sazu.si 